The Justice Dilemma 
A VOLUME IN THE SERIES

Cornell Studies in Security Affairs

Edited by Robert J. Art, Robert Jervis, and Stephen M. Walt

A list of titles in this series is available at cornellpress.cornell.edu. 


\section{The Justice Dilemma}

Leaders and Exile in an Era of Accountability

\section{DANiel KrCMARIC}

Cornell University Press

Ithaca and London 
Cornell University Press gratefully acknowledges receipt of a grant from the Kaplan Institute for the Humanities, Northwestern University, which aided in the publication of this book.

\section{Copyright $@ 2020$ by Cornell University}

All rights reserved. Except for brief quotations in a review, this book, or parts thereof, must not be reproduced in any form without permission in writing from the publisher. For information, address Cornell University Press, Sage House, 512 East State Street, Ithaca, New York 14850. Visit our website at cornellpress.cornell.edu.

First published 2020 by Cornell University Press

Printed in the United States of America

Library of Congress Cataloging-in-Publication Data

Names: Krcmaric, Daniel, 1986- author.

Title: The justice dilemma : leaders and exile in an era of accountability / Daniel Krcmaric.

Description: Ithaca [New York] : Cornell University Press, 2020. I Series: Cornell studies in security affairs | Includes bibliographical references and index.

Identifiers: LCCN 2020001955 (print) | LCCN 2020001956 (ebook) | ISBN 9781501750212 (hardcover) I ISBN 9781501750236 (pdf) । ISBN 9781501750229 (epub)

Subjects: LCSH: International criminal law. I Criminal justice, Administration of-International cooperation. I Heads of state-Legal status, laws, etc. I Exile (Punishment). I International crimes-Prevention. I Political atrocities-Prevention. I Civil war. Classification: LCC KZ7235 .K73 2020 (print) I LCC KZ7235 (ebook) | DDC 341.6/9-dc23

LC record available at https:/ /ccn.loc.gov/2020001955

LC ebook record available at https://lccn.loc.gov/2020001956

Cover photograph: Nigerian peacekeepers wave good-bye to the plane carrying former Liberian President Charles Taylor to exile in Nigeria. August 11, 2003, Monrovia, Liberia. Photograph by Chris Hondros / Getty Images News via Getty Images. 